Vol. 2 No. 2 Juli 2019

ISSN 2614-2775

e-ISSN 2621-8143
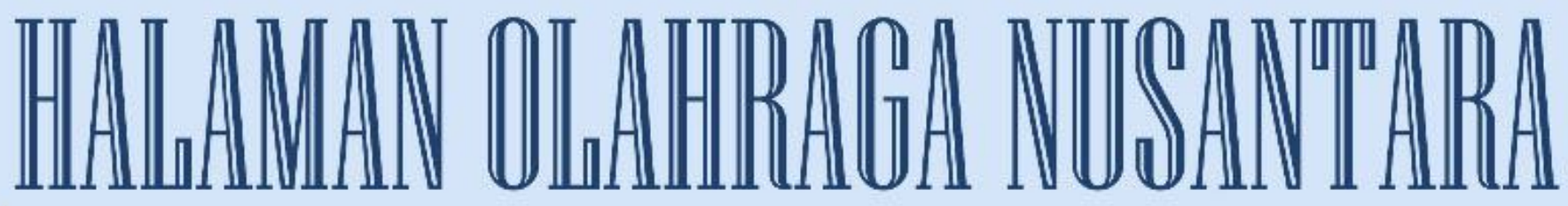

Surnal @lmu Xeolahragaan

Diterbitkan Oleh:

Program Studi Pendidikan Olahraga

Fakultas Keguruan dan Ilmu Pendidikan

Universitas PGRI Palembang

\begin{tabular}{|c|c|c|c|c|c|}
\hline Jurnal & Volume & Nomor & Halaman & Palembang & ISSN/e-ISSN \\
\hline IIalaman Oahrayg Ninsantarata & 2 & 2 & $97-197$ & 2019 & $\begin{array}{c}2614-2775 / \\
2621-8143\end{array}$ \\
\hline
\end{tabular}


Halaman Olahraga Nusantara (Jurnal Ilmu Keolahragaan)

P-ISSN 2614-2775

Volume 2, No. 2, Januari 2019

E-ISSN 2621-8143

\section{DAFTAR ISI}

Hasil Penelitian

Halaman

Penerapan Model Permainan Rounders Yang Dimodifikasi Terhadap Kemampuan Gerak Dasar Murid Sd Negeri Paccinongan Kabupaten Gowa

- Benny B, M.Rachmat Kasmad

Pelaksanaan Kegiatan Belajar Mengajar Pendidikan Jasmani di Sekolah Dasar Inklusi

- Bambang Gatot Sugiarto

Pengaruh Metode Latihan Terhadap Daya Tahan Fisik Siswa Ekstrakurikuler Sepak Bola Sma N 2 Tanjung Raja

- Mutiara Fajar.

Survei Minat Member Yang Mengikuti Fitness Pada Pusat Kebugaran Kota Palembang

- Hengki Kumbara.

Peningkatan Pengaruh Latihan Kelincahan Terhadap Kemampuan Menggiring Bola Pada Siswa Sma Negeri 3 Samarinda

- Ruslan, Nurjamal

Penerapan Permainan Dengnan Media Swiss Ball Untuk Meningkatkan Kelentukan Lower Back (Pada Mahasiswa Kop Aerobic Gymnastics Universitas Negeri Jakarta)

- M Dian Susanto, Sri Nuraini $141-153$

Patrol Multiguna Sebagai Alternatif Media Pembelajaran Tolak Peluru Di Smp Negeri 1 Sei Balai Kabupaten Batu Bara Tahun Ajaran 2017/2018

- Joko Priono $154-166$ 
Kecerdasan Gerak Dalam Pendidikan Jasmani

- Hilda Oktriyeni....................................................................... 167-176

Analisis Kesalahan Tendangan Atlet Pencak Silat Universitas PGRI Palembang

- Bayu Iswana............................................................................ 177-185

Pengaruh Metode Pembelajaran Dan Kriteria Layanan Bantuan:

Meningkatkan Gerak Dasar Lompat Jauh Gaya Jongkok Siswa Tunagrahita Ringan Pada Pembelajaran Penjasorkes SLB PKK Bandar Lampung

- Rachmi Marsheilla Aguss.............................................................. 186-197 


\title{
KECERDASAN GERAK DALAM PENDIDIKAN JASMANI
}

\author{
Oleh: Hilda Oktriyeni \\ (Dosen Universitas Karimun)
}

\begin{abstract}
Abstrak
Di dalam dunia pendidikan Indonesia, olahraga telah masuk didalam kurikulum dan menjadi mata pelajaran wajib dituntaskan disetiap jenjang pendidikan wajib belajar.Tenaga pendidik juga telah dimaksimalkan dengan kualifikasi untuk seorang guru olahraga adalah minimal sarjana strata satu dan dosen minimal sarjana strata dua.Olahraga dipandang sebagai salah satu tingkat kecerdasan yang sebenarnya wajib dilatih oleh manusia yaitu kecerdasan motorik.Kecerdasan motorik merupakan kemampuan manusia didalam melakukan aktifitas yang melibatkan anggota tubuh dengan benar, baik yang didapat secara pribadi maupun yang dipelajari. Dengan kata lain kecerdasan motorik bisa dikatakan salah satu faktor yang mempengaruhi kesuksesan pembelajaran pendidikan jasmani. Mengetahui dan mempelajari kemampuan belajar gerak peserta didik sangatlah penting agar seorang pendidik khususnya pendidikan olahraga dapat mengetahui kelebihan dan kekurangan seorang peserta didiknya, agar nantinya dapat menyelaraskan gaya mengajar dengan program serta perencanaan, fasilitas yang dibutuhkan, dan lain-lain.
\end{abstract}

Kata Kunci: Pendidikan Indonesia, Tenaga Pendidik, Kecerdasan Motorik

\section{MOTORIK INTELLIGENCE IN PHYSICAL EDUCATION}

\begin{abstract}
In Indonesian education, sports have entered the curriculum and become subjects must be completed at every level of compulsory education. Educators have also been maximized with the qualifications for sports teachers are a minimum of a bachelor's degree and a minimum of two undergraduate lecturers. Sport is seen as one level of intelligence that actually needs to be trained by humans, namely motor intelligence. Motor intelligence is the ability of humans to carry out activities that involve members of the body properly, both those obtained personally and learned. In other words, motor intelligence can be said to be one of the factors that influence the success of physical education learning. Knowing and learning student learning skills is very important so that an educator especially sports education can find out the strengths and weaknesses of a student, so that later can align the teaching style with the program and planning, facilities needed, and others.
\end{abstract}

Keywords: Indonesian Education, Teacher, Motorik Intelligence 


\section{A. PENDAHULUAN}

Olahraga merupakan salah satu unsur yang sangat berpengaruh dan sudah menjadi suatu kebutuhan dalam kehidupan manusia. Dalam lain hal olahraga juga menjadi sikap dan karakter dari seorang manusia, karena didalamnya terdapat berbagai aktifitas yang berkaitan dengan perilaku manusia. Oleh karena itu, pembinaan dan pengembangan olahraga diharapkan mampu meningkatkan kualitas manusia yang diarahkan pada kesegaran jasmani, pembentuk watak, kepribadian, dan mental.Pembinaan olahraga merupakan bagian yang tidak terpisahkan dari pembinaan secara keseluruhan.Pembinaan olahraga tidak hanya ditujukan untuk meningkatkan kualitas fisik masyarakat saja, tetapi juga untuk menggalang rasa persatuan dan kesatuan bangsa.

Dewasa ini telah terlihat bahwa olahraga merupakan salah satu unsur yang sangat berpengaruh dan sudah menjadi suatu kebutuhan dalam kehidupan manusia. Oleh karena itu, pembinaan dan pengembangan olahraga diharapkan mampu meningkatkan kualitas manusia yang diarahkan pada kesegaran jasmani, pembentuk watak, kepribadian, dan mental.Pembinaan olahraga merupakan bagian yang tidak terpisahkan dari pembinaan secara keseluruhan.Pembinaan olahraga tidak hanya ditujukan untuk meningkatkan kualitas fisik masyarakat saja, tetapi juga untuk menggalang rasa persatuan dan kesatuan bangsa.

Olahraga dapat mengharumkan nama bangsa di dunia internasional. Hal ini menunjukkan bahwa pembinaan di bidang olahraga sangat penting dan tidak bisa diabaikan karena memiliki peranan yang sangat besar dalam mewujudkan cita-cita pembangunan nasional.Di samping menjadi kebutuhan untuk mencapai kebugaran jasmani, olahraga juga dikembangkan untuk mencapai prestasi di masing-masing cabang olahraga yang dibina dan dikembangkan.Dengan kemajuan ilmu pengetahuan dan teknologi, para pakar olahraga banyak menemukan penemuan-pemuan baru, baik dari segi teori-teori olahraga, teknikteknik latihan, maupun dalam penemuan peralatan yang canggih yang sangat menunjang untuk meningkatkan prestasi olahraga.

Di Indonesia sendiri, sektor olahraga telah menjadi perhatian yang sangat serius oleh pemerintah.Didalam dunia pendidikan Indonesia, olahraga telah masuk 
didalam kurikulum dan menjadi mata pelajaran wajib dituntaskan disetiap jenjang pendidikan wajib belajar.Tenaga pendidik juga telah dimaksimalkan dengan kualifikasi untuk seorang guru olahraga adalah minimal sarjana strata satu dan dosen minimal sarjana strata dua. Hal lain yang menunjukkan betapa seriusnya Indonesia didalam pembinaan olahraga adalah mengadakan kejuaraan olahraga tingkat pelajar dan juga memberikan ruang untuk kegiatan ekskul olahraga disetiap tingkat pendikan didalam pendidikan. Oleh karena itu kita dapat mengetahui bahwa pendidikan merupakan dasar dari pengembangan olahraga dan prestasinya.

Pengembangan dan pembinaan olahraga didalam dunia pendidikan Indonesia telah dilakukan dengan sangat serius, setiap kejuaraan olahraga diadakan sesuai dengan cabang olahraga masing-masing dan yang berprestasi mendapatkan beasiswa dan pembinaan lanjutan. Hal yang sama juga dilakukan oleh setiap instansi pendidikan, setiap sekolah melakukan berbagai macam cara pembinaan dalam setiap cabang olahraga. Pelatih yang berlisensi, program latihan yang terstruktur, jadwal latihan, kegiatan ekskul yang terjadwal, sarana dan prasarana semuanya difasilitasi oleh setiap sekolah dalam pembinaan olahraga.

Olahraga secara umum mungkin hanya suatu hal yang melibatkan aktifitas fisik semata, namun pengertian ini akan berubah jika sudah terkait dengan kecabangan, pendidikan, dan prestasi olahraga. Didalam dunia pendidikan, olahraga dipandang sebagai salah satu tingkat kecerdasan yang sebenarnya wajib dilatih oleh manusia yaitu kecerdasan motorik.Kecerdasan motorik merupakan kemampuan manusia didalam melakukan aktifitas yang melibatkan anggota tubuh dengan benar, baik yang didapat secara pribadi maupun yang dipelajari. Dengan kata lain kecerdasan motorik bisa dikatakan salah satu faktor yang mempengaruhi kesuksesan pembelajaran pendidikan jasmani.

\section{Pendidikan Jasmani}

Menurut Samsudin (2013) pendidikan jasmani adalah suatu proses pembelajaran melalui aktivitas jasmani yang didesain untuk meningkatkan kebugaran jasmani, mengembangkan keterampilan motorik, pengetahuan dan perilaku hidup sehat dan aktif, sikap sportif dan kecerdasan emosi. Lingkungan 
belajar diatur secara seksama untuk meningkatkan pertumbuhan dan perkembangan seluruh ranah, jasmani, psikomotor, kognitif, dan afektif setiap siswa. Dari penjelasan teori diatas dapat di artikan bahwa pendidikan jasmani merupakan suatu cara yang dilakukan manusia dalam memperoleh pengetahuan olahraga dan mengembangkannya sesuai dengan pengalaman sehingga berdampak pada perubahan pola pikir, prilaku, dan karakter seseorang dalam melakukan aktivitas jasmani kearah yang lebih baik.

Didalam pengembangan keterampilan olahraga melalui pendidikan jasmani terdapat dua proses kegiatan yang akan dilakukan untuk tercapainya tujuan pendidikan tersebut yaitu kegiatan intrakurikuler dan kegiatan ekstrakurikuler. Kegiatan intrakurikuler menurut KBBI online (2016) adalah kegiatan siswa disekolah atau mahasiswa di kampus yang sesuai dan sejalan dengan komponen kurikulum. Sedangkan kegiatan ekstrakurikuler adalah kegiatan peserta didik diluar jam belajar kurikulum standard dan wajib. Walaupun dilaksanakan diluar jam belajar wajib akan tetapi kegiatan ekstrakurikuler berperan penting dalam suksesnya proses pengajaran intrakurikuler.

\section{Kemampuan Motorik}

Kemampuan motorik adalah hal yang harus dipahami oleh seorang pendidik disamping minat dan motivasi belajar, terutama di dalam pendidikan jasmani hal tersebut merupakan penunjang dalam meraih kesuksesan belajar dan berprestasi dalam bidang olahraga. Didalam olahraga aspek yang dikategorikan kemampuan motorik diantaranya adalah motor ability dan motor educability.

\section{a. Motor Ability}

Bakat adalah hal yang harus dipahami oleh seseorang disamping minat dan motivasi, khususnya didalam olahraga hal tersebut merupakan penunjang dalam meraih kesuksesan dan berprestasi. Bakat merupakan faktor bawaan dan pengaruh lingkungan, didalam olahraga aspek yang dikategorikan bakat diantaranya adalah motor educability dan motor ability.

Dalam proses belajar gerak yang perlu diperhatikan adalah kemampuan gerak yang mendukung keterampilan itu sendiri. Sebagian besar olahraga prestasi membutuhkan ketangkasan dari atletnya baik cabang olahraga yang bersifat 
perorangan mau pun yang beregu, termasuk salah satunya olahraga bolabasket. La Kamadi (2011) menjelaskan pengertian motor ability, yaitu:

Kecakapan gerak umum dan tes gerakan-gerakan umum yang dapat diajarkan telah menunjukkan bahwa otoritas masa lampau anak merupakan parameter gerak umum yang sifatnya fundamental untuk keberhasilan partisipasi anak dalam cabang-cabang olahraga mau pun permainan.Kecakapan-kecakapan gerak fundamental ini diperkirakan ditentukan oleh faktor genetis dan stimulasi (rangsangan) dari lingkungan yang dikenalnya sejak dini.

Istilah keterampilan itu sendiri memiliki beberapa pengertian yang telah dipakai dalam beberapa versi dalam literature tentang prilaku motorik. Yang lazim dipakai ialah keterampilan dipandang sebagai suatu perbuatan atau tugas, dan lainnya sebagai sebuah indikator dari tingkat kemahiran. Apabila keterampilan dipandang sebagai aksi motorik atau pelaksanaan suatu tugas, keterampilan itu akan terdiri dari sejumlah respon motorik dan persepsi yang diperoleh melalui belajar. Keterampilan motorik dapat dipahami sebagai indikator dari tingkat kemahiran atau penguasaan sesuatu hal yang memerlukan gerak tubuh.Sebagai indikator dari tingkat kemahiran, keterampilan diartikan sebagai kemampuan yang diperagakan oleh seseorang dalam menjalankan suatu tugas berkaitan dengan dengan pencapaian tujuan yang diharapkan, maka seseorang tersebut dikatakan makin terampil.Seorang pemain bolatangan yang mampu memasukkan bola meskipun dijaga oleh 2-3 pemain lawan secara ketat disebut sebagai pemain terampil.Istilah terampil juga dapat dinyatakan untuk menggambarkan tingkat kemahiran seseorang melaksanakan suatu tugas. Seorang pemula yang baru mengenal bagimana cara bermain bolatangan, akan memperlihatkan koordinasi gerak yang kaku, operan dan tembakan yang sering meleset, atau dribel yang kacau, kategori pemain tersebut dapat digolongkan kurang terampil.

Kemampuan motorik dan keterampilan bukanlah sebagai konsep yang sama pengertiannya. Hal ini seperti yang dikatakan Gusril (2007:11) yaitu, "seseorang yang memiliki kemampuan motorik tinggi, diduga akan lebih berhasil dalam menyelesaikan tugas keterampilan motorik khusus". Jadi, dapat dikatakan bahwa kemampuan motorik adalah kecakapan, kekuatan ,dan kesanggupan dalam 
melakukan suatu gerakan. Pengaruh faktor biologis dianggap sebagai kekuatan utama yang berpengaruh terhadap kemampuan motorik dasar seseorang, dan nantinya kemampuan motorik dasar itulah yang kemudian berperan sebagai landasan bagi perkembangan keterampilan.

\section{b. Motor Educability}

Cratty dalam Lutan (1988) mengatakan istilah motor educability adalah sudah menjadi suatu kata yang cukup popular di kalangan aktivis olahraga, hal ini dikarenakan membahas tentang cepat lambatnya seseorang menguasai suatu keterampilan baru secara cermat. Dari penjelasan diatas dapat diketahui bahwa kemampuan motor educability seseorang dapat menunjang proses dalam mempelajari sebuah keterampilan gerak.

Motor educability berasal dari bahasa Inggris, yaitu motor artinya bergerak, educatic artinya pengetahuan, dan ability artinya kemampuan. Dari rangkaian kata diatas terbentuk istilah motor educability yang memberikan pengertian kemampuan umum bagi seseorang dalam menguasai atau menerima gerakan baru. Dalam memperoleh kemampuan motor educability tidaklah harus melalui proses latihan layaknya kondisi fisik. Tetapi, kemampuan tersebut dapat diperoleh dari pertumbuhan yang baik serta usia yang nantinya akan mempengaruhi kemampuan bergerak, berpikir, dan belajar termasuk kecakapan dasar atau intelegensi yang dimiliki oleh setiap individu. Hal ini seperti yang dijelaskan oleh Scanidt dalam Lutan (1988:76) menjelaskan bahwa "Kemampuan diartikan sebagai ciri individu yang diwariskan dan relatif abadi yang mendasari serta medukung terbentuknya keterampilan." Namun kita tetap tidak boleh mengabaikan latihan, karena latihan merupakan faktor pendukung dalam meningkatkan secara totalitas baik aspek fisik maupun psikis.

Cratty dalam Lutan (1988) menjelaskan bahwa "motor educability diartikan sebagai kemampuan umum untuk mempelajari tugas secara cepat dan cermat". Tapi, Sekalipun motor educabilitymerupakan kemampuan dasar, akan berkembang lebih baik apabila didukung oleh kondisi fisik yang baik melalui latihan atau berolahraga. Seorang atlet akan memiliki kemampuan motor 
educability yang baik apabila rajin serta aktif dalam berlatih, sehingga nantinya kemampuan tersebut akan memberikan kontribusi kepada individu agar mampu mempelajari secara cepat dan cermat kecakapan dasar dan keterampilan motorik.

Jika seorang atlet memiliki kemampuan motor educability yang baik memperhatikan contoh suatu gerakan, kemudian melakukannya sendiri, maka nantinya hal tersebut akan memberikan kontribusi yaitu persepsi kinestesis yang membutuhkan konsentrasi untuk merasakan suatu gerakan sehingga nantinya atlet akan lebih cepat menyerap suatu gerakan. Hal ini seperti yang dikatakan Gusril (2007:11) yaitu, "seseorang yang memiliki kemampuan motorik tinggi, diduga akan lebih berhasil dalam menyelesaikan tugas keterampilan motorik khusus". Kemampuan motor educability atlet perlu diketahui oleh pelatih, karena saat beraktivitas di lapangan, kondisi fisik dan karakter psikologis akan menjadi suatu kesatuan yang saling berinteraksi. Dengan mengetahui kemampuan motor educability atlet maka nantinya pelatih akan melakukan penyesuaian kembali program latihan yang cocok bagi atlet berdasarkan prinsip-prinsip latihan, dan tujuan yang akan dicapai. Sehingga nantinya pelatih dapat menjadikan keterampilan motorik seperti motor educability pada atlet sebagai tujuan untuk mencapai suatu prestasi olahraga.

Di dalam proses pengembangan kemampuan motor educability, para pelatih perlu mempelajari kondisi atlet agar penyesuaian metode latihan cocok bagi atlet sendiri berdasarkan prinsip latihan dan kemudian tujuan apa yang hendak dicapai. Selain itu, setiap pelatih akan mempunyai gambaran tersendiri tentang keadaan atlet dari awal proses latihan sampai kepada inti dan kelangsungan proses latihan itu sendiri.

Kualitas potensial motor educability memberikan gambaran mengenai kemampuan seseorang dalam mempelajari gerakan-gerakan yang baru dengan mudah. Didalam mempelajari keterampilan bolabasket kemampuan motor educability menentukan kualitas teknik yang akan diperoleh oleh atlet, hal ini berhubungan dengan cepat tidaknya seseorang atlet dalam mempelajari sebuah gerakan ketika ingin menguasai suatu keterampilan pada cabang olahraga tertentu. Misalnya ketika mempelajari suatu teknik ada sebagian atlet yang mengatakan 
bahwa gerakannya mudah dan ada sebagian lagi yang mengatakan bahwa gerakannya sulit, dalam hal ini jika pelatih mengukur tingkat motor educability atlet tersebut maka akan didapatlah program latihan yang tepat untuk setiap atlet.

\section{B. METODE PENELITIAN}

Kegiatan belajar dan mengajar pendidikan jasmani di sekolah, seharusnya keseluruhan potensi olahraga peserta didik dapat dikembangkan dan dibina, sehingga nantinya mereka dapat menggunakan dan memanfaatkan potensi yang miliki semaksimal mungkin baik di secara pribadi dan juga untuk masyarakat serta lingkungan sekitar. Dalam hal ini seorang yang bergelut didalam dunia olahraga khususnya bidang pendidikan olahraga memahami setiap aspek yang mempengaruhi perkembangannya sehingga nanti dapat berguna dalam proses pembelajaran itu sendiri, hal ini sesuai dengan pernytaan Syafruddin (2013):

"Pada dasarnya kegiatan intrakurikuler dan ekstrakurikuler memberikan kesempatan kepada siswa untuk mengembangkan kemampuan belajar motoriknya yang disalurkan melalui kegiatan kecabangan olahraga. Belajar motorik dalam pembinaan olahraga disekolah adalah upaya siswa melalui belajar dan berlatih baik dalam kegiatan intrakurikuler maupun kegiatan ekstrakurikuler untuk menguasai suatu bentuk keterampilan cabang olahraga sehingga ia berprestasi dalam suatu cabang olahraga tertentu sesuai dengan pilihannya. Dengan kata lain terjadi peningkatan kemampuan dan keterampilan yang dimilikinhya."

Motor educability merupakan faktor yang penting didalam pengembangan dan pembentukan keterampilan olahraga, Hal ini disampaikan Gusril (2007: 11) yaitu, "seseorang yang memiliki kemampuan motorik tinggi, diduga akan lebih berhasil dalam menyelesaikan tugas keterampilan motorik khusus". Syafruddin (2013: 144) juga mengatakan:

"Orang yang berbakat dan memiliki kemampuan belajar gerak yang baik tentu saja lebih cepat memperoleh suatu keterampilan teknik jika dibandingkan dengan orang yang tidak atau kurang berbakat dan rendah kemampuan intelegensinya (kemampuan kognitifnya)."

Seorang pendidik akan mempunyai rancangan tersendiri tentang bagaimana keadaan siswa/siswi dari awal proses kegiatan pembelajaran sampai kepada kegiatan inti serta kelangsungan proses pembelajaran itu sendiri. Hal ini 
seperti yang dikatakan Kirkendall, et.al, (1987) di dalam jurnal I Ketut dkk, (2013) bahwa kualitas potensial motor educability memberikan gambaran mengenai kemampuan seseorang dalam mempelajari gerakan-gerakan yang baru dengan mudah. Makin tinggi tingkat potensial motor educabilitynya, berarti derajat penguasaan terhadap gerakan-gerakan baru makin mudah.

Melalui beberapa teori di atas maka dapat dipahami bahwa mengetahui dan mempelajari kemampuan belajar gerak peserta didik sangatlah penting agar seorang pendidik khususnya pendidikan olahraga dapat mengetahui kelebihan dan kekurangan seorang peserta didiknya, agar nantinya dapat menyelaraskan gaya mengajar dengan program serta perencanaan, fasilitas yang dibutuhkan, dan lainlain.

\section{KESIMPULAN}

Motor ability dan Motor Educability merupakan unsur salah satu faktor pendukung dalam berkembangnya potensi dan keterampilan olahraga, oleh karena itu para pendidik dan peserta didik dapat mengetahui dan memahami unsur tersebut agar nantinya mereka akan lebih teliti dalam mengetahui aspek-aspek potensi dan keterampilan olahraga mereka sendiri.

\section{DAFTAR PUSTAKA}

Gusril.(2007). "Peningkatan Kemampuan Motorik Atlet Sekolah Dasar: Pidato Pengukuhan Guru Besar dalam Pedagogik Olahraga papa Fakultas Ilmu Keolahragaan Universitas Negeri Padang”. Padang: Universitas Negeri Padang.

Kamadi, La. (2011). "Pengaruh Metode Keseluruhan dan Metode Bagian terhadap Penguasaan Keterampilan Dasar Bola Voli Atlet SLTP dengan Tingkat MotorEducability Tinggi dan Rendah: Suatu Studi Eksperimen di SLTP Negeri I Sungguminasa Kabupaten Gowa Sulawesi Selatan”.Retrieved from Jurnal Online Volume 9 Nomor 1 Januari- April 2011. http://digilib.unm.ac.id/download.php?id=106 Makasar: Fakultas Ilmu KeolahragaanUniversitar Negeri Makasar. 
Lutan, Rusli.(1988). Belajar Keterampilan Motorik, Pengantar Teori dan Metode. Jakarta: Departemen Pendidikan dan Kebudayaan Direktorat Jenderal Perguruan Tinggi Proyek Pengembangan Pendidikan Tinggi dan Tenaga Kependidikan.

Samsudin.(2013). Kurikulum Pendidikan Jasmani Dan Olahraga. Jakarta: UNJ Press.

Semarayasa, I Ketut dkk.(2013). "Pengaruh Metode Pembelajaran dan Tingkat Motor Educability (Me) terhadap Keterampilan Dasar Smash Kedeng dalam Permainan Sepak Takraw di SMPN 4 Kubutambahan".Retrieved from Jurnal Online Vol. 2, No. 1, April 2013. Singaraja: Jurusan Pendidikan Jasmani Kesehatan dan Rekreasi, Fakultas Olahraga dan Kesehatan Universitas Pendidikan Ganesha.

Syafruddin.(2013). Ilmu Kepelatihan Olahraga: Teori dan Aplikasinya dalam Pembinaan Olahraga. Padang: UNP Press.

http://KBBI-Online.co.id/definisi-intrakurikuler/.Retrieved from http://KBBIonline.co.id. 